\title{
Retrospective Evaluation of Hospitalized Patients Treated with Pleural Drainage Due to Pleural Effusion
}

\author{
Hastanede Yatırılarak Tedavi Edilmiş ve Plevral Effüzyon Nedeniyle Plevral \\ Drenaj Uygulanmış Hastaların Retrospektif Olarak Değerlendirilmesi
}

\author{
Servet Özdemir', (D) Faruk Karandere2, (D) Necati Çıtak1, (D) Mustafa Özer Ulukan³, (D) Abdulbaki Kumbasar² \\ ${ }^{1}$ University of Health Sciences Turkey, Bakırköy Dr. Sadi Konuk Training and Research Hospital, Clinic of Thoracic Surgery, Istanbul, Turkey \\ 2University of Health Sciences Turkey, Bakırköy Dr. Sadi Konuk Training and Research Hospital, Clinic of Internal Medicine, Istanbul, Turkey \\ ${ }^{3}$ Istanbul Medipol University Faculty of Medicine, Department of Cardiovascular Surgery, Istanbul, Turkey
}

\begin{abstract}
Objective: Pleural effusion (PE) is a common pathological condition that can occur during the clinical course of many diseases. This study aimed to retrospectively evaluate the clinical features and treatment results of patients with pleural fluid drainage due to PE.

Methods: A retrospective analysis was performed in the study with 103 patients between January 2020 and March 2021 , who had pleural drainage due to PE. The posteroanterior and lateral chest radiographs were evaluated.

Results: A total of 103 patients were included in the study, with an overall mean age of 62.5 years minimum: 24, maximum: 91 years. Most patients had three or more comorbid diseases ( $n=53,51.5 \%$ ). The majority of patients had drainage using a pleural catheter $(n=97,94.2 \%)$. Cytological examination of the pleural fluid revealed malignancy in 5 (4.9\%) patients, whereas 89 (86.4\%) were discharged during follow-up, and $14(13.6 \%)$ had mortality. In the patients who died, more fluid with exudate characteristics at a level close to statistical significance was detected. Malignant cells were detected in the pleural fluid in $10 \%$ of patients with primary malignant cases $(n=50)$, whereas no malignant cell was found in the pleural fluid of patients without malignancy diagnosis $(n=53)$, with a statistically significant difference between patients with and without malignancy. The total length of hospital stay was significantly higher in patients undergoing a second surgical procedure.

Conclusion: Patients undergoing pleural fluid drainage had at least one systemic disease. The most common systemic disease in patients was a cardiac disease, followed by malignant disease. "No malignant cells were detected in the fluids of patients without primary malignancy," in the cytology. In addition, the rate of second pleural surgery is high in PE cases, which further prolongs the length of hospitalization of these patients.

Keywords: Pleural effusion, transudate-exudate, pleural catheter, pleural drainage, thoracentesis
\end{abstract}

\section{öz}

Amaç: Plevral efüzyon (PE) birçok hastalığın klinik seyri sırasında ortaya çıkabilen ve sık görülebilen bir patolojik durumdur. Bu çalışmada, iç hastalıkları kliniğinde yatırılarak tedavi edilmiş ve PE nedeniyle plevral sıvı drenaj uygulanmış hastaların klinik özelliklerini ve tedavi sonuçlarını retrospektif olarak değerlendirmeyi amaçlanmıştır.

Gereç ve Yöntem: Çalışmada Ocak 2020 ile Mart 2021 tarihleri arasında iç hastalıkları kliniğinde yatıılarak tedavi edilmiş ve PE nedeniyle plevral drenaj uygulanmıs 103 hasta geriye dönük olarak incelenmiştir. Bu hastalardaki mevcut komorbit hastalıklar kayıt edilmiştir. Bütün hastaların çekilmiş olan posteroanterior ve lateral akciğer grafileri incelenerek sıvı miktarları değerlendirildi. Olguların demografik özellikleri, sıvı analizinde dikkat çeken özellikleri, torasentez dışında kullanılan tanı yöntemleri, drenaj için kullanılan cerrahi yöntemler, işleme ait komplikasyonlar, hastaların yatış süresi ve sağkalım durumları değerlendirildi.

Bulgular: Hastaların yaş ortalaması 62,5 yıl minimum: 24, maksimum: 91 yıl idi. Yüz üç hastanın 58'i kadın (\%56,3) ve 45'i erkekti (\%43,7). Hastaların çoğunluğunda üç ve üzeri komorbidit hastalık mevcuttu ( $n=53, \% 51,5)$. Hastaların çoğunluğuna plevral katater ile drenaj uygulanmıştı $(n=97, \% 94,2)$. Drenaj sonrasında hastaların \%10,7'sinde $(n=11)$ cerrahi girişime ait komplikasyon izlendi. Plevral sıvının sitolojik incelenmesinde hastaların beşinde $(\% 4,9)$ plevral sıvıda maligniteye rastlandı. Toplam drenaj süresi ortalama 8,8 gün iken (min: 1 gün, maks: 68 gün, IQR=7) toplam hastanede kalış süresi 23,6 gün (min: 3, maks: 103, IQR=19) olarak hesaplandı. Takipte hastaların 89'u taburcu edilirken (\%86,4), 14'ü

Address for Correspondence: Servet Özdemir, University of Health Sciences Turkey, Bakırköy Dr. Sadi Konuk Training and Research Hospital, Clinic of Thoracic Surgery, Istanbul, Turkey

Phone: +90 5053572434 E-mail: servetozdemir74@hotmail.com ORCID ID: orcid.org/0000-0002-8458-0772

Cite as: Özdemir S, Karandere F, Çıtak N, Ulukan MÖ, Kumbasar A. Retrospective Evaluation of Hospitalized Patients Treated with Pleural Drainage Due to Pleural Effusion. Med J Bakirkoy 2021;17:304-311 
eks olmuştu $(\% 13,6)$. Eksitus olan hastalarda istatistiksel anlamlıı̆ga yakın düzeyde daha fazla eksüda vasfında sıvı saptandı. Primer malignitesi mevcut olan hastaların ( $n=50) \% 10$ 'unda plevral sıvıda malign hücre saptanırken malignite tanısı olmayan hastaların ( $n=53$ ) hiçbirinde plevral sıvıda malign hücre saptanmamıştı ve bu aradaki fark istatistiksel olarak anlamlıydı $(p=0,02)$. İkinci kez cerrahi girişim gerektiren hastalarda hastanede kalış süresi anlamlı olarak yüksek bulundu.

Sonuç: Pleral sıvı drenajı uygulanmış hastalarda en az bir sistemik hastalık mevcuttu. Hastalarda en sık görülen sistemik hastalık kardiyak hastalıklarken ikinci sırada ise malignansiler yer almaktadır. Drenaj sonrası komplikasyon görülebilmekte ancak majör komplikasyon gelişmemektedir. Mortaliteyi etkileyen faktörler sıklıkla hastaya ait olan primer sistemik hastalığa bağlıydı. Primer maligniteye sahip olmayan hastalarda plevral sıvının sitolojik incelemesinde malign hücreye rastlanmadı. Ayrıca PE'lerde ikinci plevral cerrahi işlem oranı yüksektir bu durum hastaların yatış süresini daha da uzatmaktadır.

Anahtar Kelimeler: Plevral effüzyon, transüda-eksüda, plevral katater, plevral drenaj, torasentez

\section{INTRODUCTION}

An abnormal amount of fluid between the parietal and the visceral pleura is expressed as pleural effusion (PE) (1). PEs may occur as a result of increased fluid release in the pleural space or decreased pleural fluid absorption. PEs are frequent conditions (2). The frequency of determining $P E$ is accepted as 4/1,000 people per year (3). That is, PE can be seen in many diseases rather than a single disease caused by pathologies that disrupt the formation and absorption mechanism of the pleural fluid (4-6).

Differential diagnosis in PE includes a wide spectrum, patient evaluation requires a systematic approach, and systemic diseases must be considered (7). Almost all systemic pathologies, such as the cardiovascular, gastrointestinal, endocrine, and genitourinary systems, and connective tissue can cause PE. Anamnesis and clinical examination of a patient with PE can guide the physician to determine if the PE is exudative or transudative. This significant distinction may also scale down the differential diagnosis and guide further research (4). Congestive heart failure is the most common cause of transudative PE. Contrarily, connective tissue diseases, such as rheumatoid arthritis, systemic lupus erythematosus, often cause exudative PE.

All these evaluations reduce unnecessary invasive procedures and shorten the time for diagnosis (8). If deemed as appropriate, the process continues with thoracentesis, and the pleural fluid that is collected is analyzed. As necessary, other examinations and procedures, such as thorax computed tomography (CT), thorax ultrasonography, magnetic resonance, and positron emission tomography/ CT pleural biopsy, as well as video-assisted thoracoscopy (VATS), and bronchoscopy, can be added (9).

This retrospective study aimed to investigate the clinical status of 103 patients with PE who had pleural drainage in the department of internal medicine and evaluate its compliance with the literature.

\section{METHODS}

Before the research, approval for the study was obtained from the Ethics committee of the University of Health
Sciences Turkey, Bakirkoy Dr. Sadi Konuk Training and Research Hospital (protocol number: 2021/96). In addition, informed consent for the patient's information was obtained from the patient(s) or a legally authorized representative before hospitalization.

This study retrospectively examined 3,768 patients hospitalized at the University of Health Sciences Turkey, Bakırkoy Dr. Sadi Konuk Training and Research HospitalInternal Medicine Clinic between January 2020 and March 2021. PE was determined in 347 (9.2\%) of these patients. Posteroanterior (PA) and lateral chest radiographs obtained at admission were examined. Considering the PA radiography, the pleural fluid amount was defined as minimal (fluid covering the costophrenic angle, not covering the entire diaphragm), moderate (fluid covering $<2 / 3$ of the hilus), and massive (fluid covering $>2 / 3$ of the hemithorax). Drainage is applied in patients with moderate and massive PE (Figures 1 and 2) in the hospital; however, drainage is not inserted in patients with minimal PE (Figure 3), except for the presence of exudative fluid. Drainage is not inserted as the first option according to the hospital procedure, except for a radiological appearance in stable respiratory and

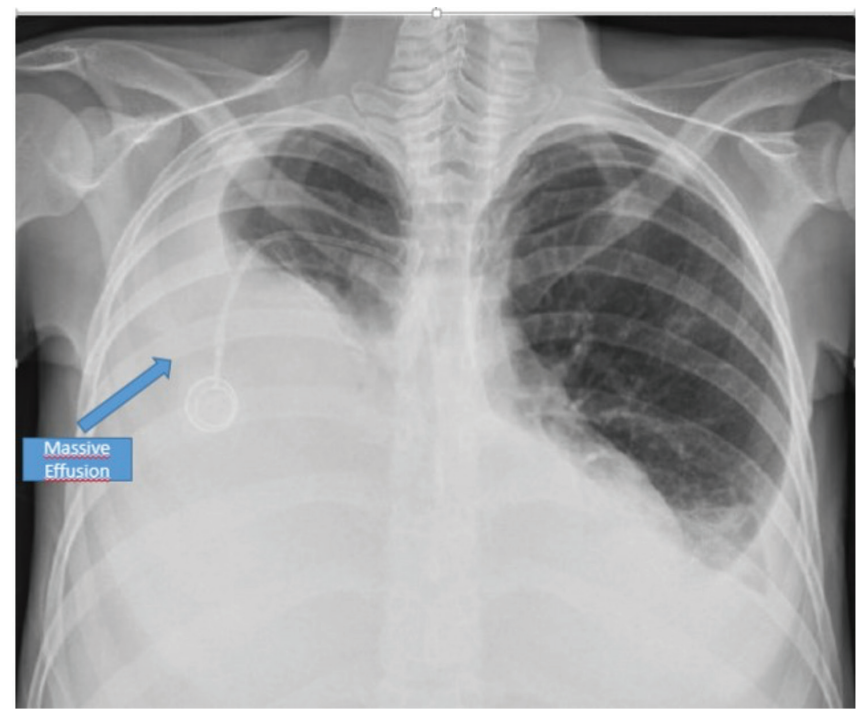

Figure 1. X-ray massive PE compromising the right pleural cavity PE: Pleural effusion 


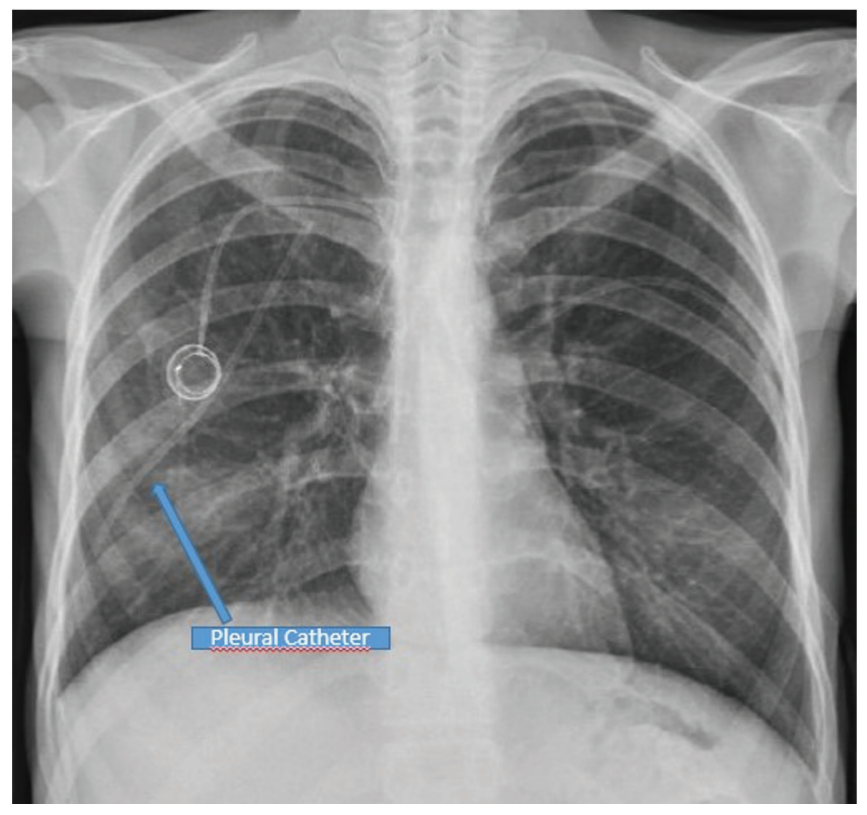

Figure 2. X-ray of the pleural cavity of figure 2 after pleural drainage with pleural catheter

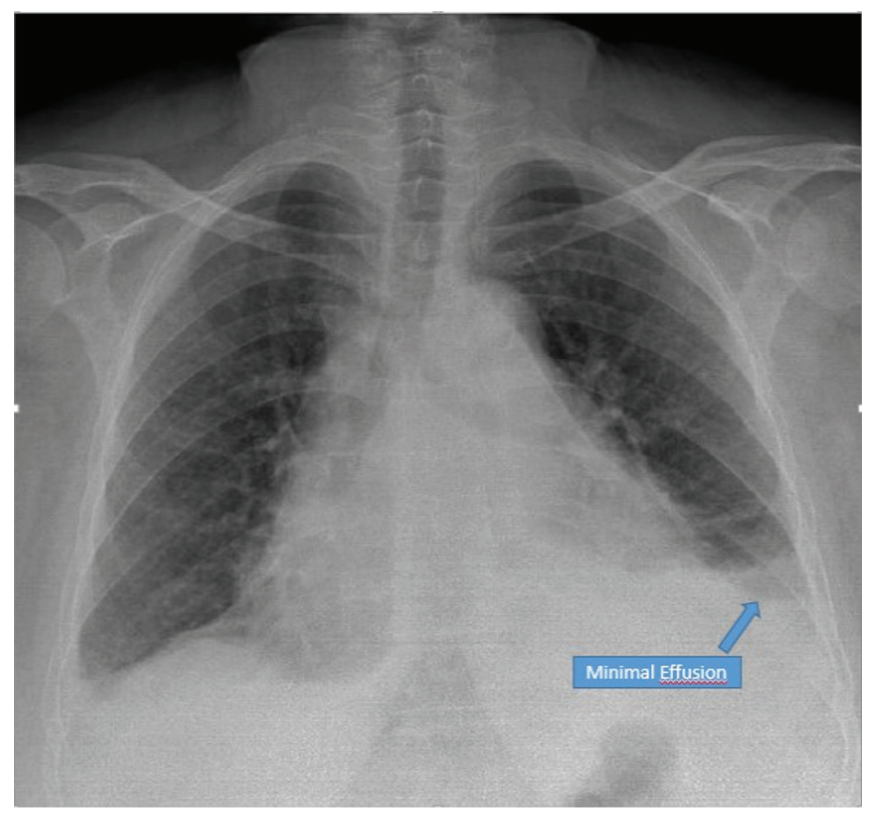

Figure 3. X-ray of minimal pleural effusion at the left costophrenic sinus indicated by arrow

hemodynamic parameters of patients with minimal PE and no deterioration in the patient's clinical course. Taking all these into consideration, 103 patients undergoing pleural drainage due to moderate and massive PE, were included in the study. These 103 patients comprise $2.7 \%$ of a total of 3,768 cases and $29.6 \%$ of 347 cases with PE.

Before the pleural catheter insertion in patients with $P E$, thoracentesis was performed, and the macroscopic appearance of the fluid sample was evaluated. The pleural catheter was inserted (8-10 Fr) in patients with serous PE. Chest drainage tube insertion (28-32 Fr) was performed for patients with a dark consistency and dense cell (empyema, chylothorax, and hemothorax). In the follow-up, the pleural catheter or chest tube was removed when the amount of pleural drainage was $<100 \mathrm{cc} /$ day and when the chest X-ray radiography showed regression in the fluid and expansion in the lungs after drainage.

During the procedure, data on age, gender, demographic characteristics, the underlying cause of $\mathrm{PE}$, comorbidities, characteristics of pleural fluid, surgical procedure, and complications during or after the surgical procedure were collected from the patient file and recorded in a previously prepared data collection form. The pleural fluid location was classified as unilateral (right or left hemothorax) or bilateral.

Comorbid diseases were grouped as cardiac, pulmonary, renal, diabetes mellitus (DM), and malignancy. Patients with coronary artery disease, congestive heart failure, hypertension, and cardiac arrhythmia were evaluated as the cardiac disease group. Patients with chronic obstructive pulmonary disease, asthma, bronchial, pneumonia, TBC, and pulmonary embolism were grouped as pulmonary disease groups. Conditions, such as chronic renal failure, acute renal failure, and kidney transplant history, were classified as renal disease. Patients diagnosed with DM before admission were included in the DM group. All patients with primary malignancy who are diagnosed before hospitalization were included in the malignant disease group. In addition, each patient may have more than one comorbidity, the number of comorbidities was divided into three subgroups as one, two, three, or more.

The drugs (such as anticoagulants) that the patient was using and those constituted a relative contraindication for surgical intervention were recorded.

All cases included in the study were differentiated as transudative or exudative based on the Light criteria with a biochemical examination in the fluid sample taken before the treatment. If one or more of the specified criteria were present, the fluid was considered to be exudate: 1) pleural fluid/serum protein of $>0.5$; 2) pleural fluid/serum lactate dehydrogenase (LDH) of $>0.6$; and 3) pleural fluid LDH higher than $2 / 3$ of the upper limit of serum LDH's optimal laboratory values (8). In the absence of any of these criteria, pleural fluid was defined as transudative. The fluid samples collected from all patients were sent to pathology for cytological malignancy examination.

After the first drainage, the pleural drainage catheter was removed in patients who were thought to be treated both medically and surgically. However, some patients required the second drainage due to pleural fluid recurrence. For 
patients who received drainage for the second time, pleural drainage duration and length of hospital stay (LOS) were recorded. Whether the patients were discharged or died during the hospitalization were examined.

\section{Statistical Analysis}

The data were entered into the Statistical Package for the Social Sciences (IBM SPSS Statistics for Windows, Version 23.0, Armonk, NY, USA) software package. Descriptive statistics were used to summarize pertinent study information. Quantitative variables were presented as mean, maximum (max), and minimum (min) values and qualitative variables were presented as percentage values. Normal distributions were tested and reported as mean values. The Student's t-test was used for comparisons between groups. Pearson's chi-squared test was used for qualitative variable analyses; however, Fisher's Exact test was used if the sample size was small. Non-parametric continuous variables, presented as median values, were compared using the Mann-Whitney $U$ test. Statistical significance was set at a p-value of $<0.05$.

\section{RESULTS}

The mean age of patients was 62.5 years [min: 24, max: 91 years, Interquartile range (IQR): 27.0], wherein 58 were female (56.3\%) and 45 were male (43.7\%). The conditions of the patients in terms of anticoagulant drug use, number of comorbidities, and subtypes of comorbidities were shown in Table 1. Most patients had three or more comorbid diseases $(n=53,51.5 \%)$. The most common comorbidities were found in the cardiac diseases group $(n=60,58.3 \%)$, followed by malignant diseases group ( $n=50,48.5 \%)$. PE was detected on the right side in 63 patients and on the left side in 32 patients, whereas bilateral in the remaining 8 patients (Table 1).

Most patients had drainage using a pleural catheter ( $n=97$, 94.2\%), whereas the remaining were drained by tube thoracostomy, and 1 was drained by VATS. Following the surgical procedures, complications related to the procedure were observed in $10.7 \%(n=11)$ of patients. The most common complication was pneumothorax $(n=10)$, whereas 1 patient developed an intrathoracic hematoma.

Considering the PE type, the transudative rate was $52.4 \%$, whereas the exudative rate was $47.6 \%$ (Table 2). As a result of pathological examinations, malignancy was found in the pleural fluid in 5 of all patients (4.9\%). The total drainage time was 8.8 days (min: 1 day, max: 68 days, IQR: 7) on average, whereas the total LOS was calculated as 23.6 days (min: 3, max: 103, IQR: 19).

Regarding PE types, a significant difference between patients with transudative and exudative fluid in terms of malignancy $(p=0.04)$ and pulmonary disease $(p=0.009)$ was found (Table 2). Exudative fluid was mostly observed in patients with cancer $(59.2 \%$ vs. $38.9 \%)$, whereas transudative fluid was more likely observed in pulmonary disease (31.5\% vs. $10.2 \%)$. A difference close to significance was also found in terms of pleurisy $(p=0.06)$. Exudative fluid was observed to be mostly bilateral, but transudative one was more leftsided. No significant difference was found between the groups in terms of other variables.

During the follow-up, 89 of patients (86.4\%) were discharged and 14 of them died (13.6\%). No statistical difference

Table 1. Demographic and clinical characteristics of patients

\begin{tabular}{ll} 
Variables & Data \\
\hline Age, year \pm SD & $62.5 \pm 16.7$ \\
\hline Sex, $n(\%)$ & $45(43.7 \%)$ \\
Male & $58(56.3 \%)$ \\
Female & $12(11.7 \%)$ \\
\hline Anticoagulant drug use, $\mathrm{n}(\%)$ & \\
\hline Number of comorbidities, $\mathrm{n}(\%)$ & $33(32.0 \%)$ \\
1 & $17(16.5 \%)$ \\
2 & $53(51.5 \%)$ \\
\hline 3 or more & $50(48.5 \%)$ \\
\hline Malignancy presence, $\mathrm{n}(\%)$ & $30(29.1 \%)$ \\
\hline DM, $\mathrm{n}(\%)$ & $60(58.3 \%)$ \\
\hline Cardiac disease group, $\mathrm{n}(\%)$ & $27(26.2 \%)$ \\
\hline Renal disease group, $\mathrm{n}(\%)$ & $22(21.4 \%)$ \\
\hline Pulmonary disease group, $\mathrm{n}(\%)$ & \\
\hline Pleural effusion side, $\mathrm{n}(\%)$ & $32(31.1 \%)$ \\
$\mathrm{L}$ & $63(61.2 \%)$ \\
Bilateral & $8(7.8 \%)$ \\
\hline
\end{tabular}

The type of surgical intervention performed first, $\mathrm{n}(\%)$

Pleural catheter

Tube thoracostomy

$97(94.2 \%)$

VATS

$5(4.9 \%)$

$1(1.0 \%)$

Surgery-related complication, $\mathrm{n}(\%)$

$11(10.7 \%)$

Type of the pleural effusion, $n$ (\%)

Transudate $54(52.4 \%)$

Exudate

$49(47.6 \%)$

Malignancy detection in pleural fluid, $n(\%) \quad 5(4.9 \%)$

Duration of drainage, day \pm SD $\quad 8.8 \pm 8.4$

Need for a second surgical procedure at

hospitalization, $\mathrm{n}(\%)$

$31(30.1 \%)$

Situation, $\mathrm{n}(\%)$

Discharge

Mortality

$89(86.4 \%)$

Length of hospitalization, day $\pm S D$

$14(13.6 \%)$

L: Left, R: Right, n: Number, SD: Standard deviation, VATS: Video-assisted thoracoscopic surgery, DM: Diabetes mellitus 
was detected in terms of variables between patients who developed mortality and were discharged (Table 3). In patients developing mortality, a more exudative fluid at a statistically significant level was observed, whereas more transudative fluid was detected in the patients who were discharged $(p=0.08)$.

Pathological examination revealed that all 5 patients with malignant cells in PE had a previous history of primary cancer (2 had gastric cancer, 1 had breast cancer, 1 had acute myeloblastic leukemia, and 1 had acute lymphoblastic leukemia). Malignant cells were detected in the pleural fluid in $10 \%$ of patients in primary malignancy cases $(n=50)$ and no malignant cell was detected in the pleural fluid of patients without a diagnosis of malignancy $(n=53)$, and the difference was statistically significant ( $p=0.02$ ).

The total LOS was determined to be significantly higher in patients undergoing a second surgical procedure compared to patients not requiring it $(31.7 \pm 12.7$ days vs. $20.1 \pm 15.6$ days, $p=0.009$ ).

\section{DISCUSSION}

In the United States, 1.4 million people have been reported to develop PE annually. The most common causes of PE are congestive heart failure, pneumonia, and cancers, whereas pulmonary embolism, viral diseases, coronary bypass surgery, cirrhosis, intra-abdominal diseases, and uremia diseases were reported to follow as less frequent (10-12). Concurrently, conditions, such as the increased number of patients with chronic diseases due to the prolongation of life expectancy and an increased incidence of malignancies, suggest that patients with PE will increase in the future. Therefore, determination for the best procedure for these patients is crucial.

In the current study, all patients undergoing drainage due to PE were found to have a comorbidity, and 3 or more comorbidities were observed simultaneously in most of them (51\%). In studies, heart failure is the most common cause of PE (8-10), followed by breast, lung, and pleural metastatic cancer (10-12).

A study evaluated 2,040 patients with malignant PE and revealed that malignancies originating from the lung $(38 \%)$, breast (17\%), lymphoma (12\%), genitourinary system (9\%), and gastrointestinal system (7\%) have been reported (13). Similar results were obtained in the current study. In heart failure, renal diseases, hypoalbuminemia, and some pulmonary diseases, pleural fluid slowly begins to regress after the disease is controlled by medical treatment (14).

Table 2. Comparison of variables according to the type of pleural effusion

\begin{tabular}{|c|c|c|c|}
\hline Variables & Transudative $(n=54)$ & Exudative (49) & $\mathrm{p}$ \\
\hline Age, year \pm SD & $63.2 \pm 17.0$ & $61.6 \pm 16.5$ & 0.574 \\
\hline $\begin{array}{l}\text { Sex, n (\%) } \\
\text { Male } \\
\text { Female }\end{array}$ & $\begin{array}{l}33(61.1 \%) \\
21(38.9 \%)\end{array}$ & $\begin{array}{l}25(51.0 \%) \\
24(49.0 \%)\end{array}$ & 0.302 \\
\hline $\begin{array}{l}\text { Number of comorbidities, } \mathrm{n}(\%) \\
1 \\
2 \\
3 \text { or more }\end{array}$ & $\begin{array}{l}18(33.3 \%) \\
7(13.0 \%) \\
29(53.7 \%) \\
\end{array}$ & $\begin{array}{l}15(30.6 \%) \\
10(20.4 \%) \\
24(49.0 \%) \\
\end{array}$ & 0.596 \\
\hline Malignancy presence, n (\%) & $21(38.9 \%)$ & $29(59.2 \%)$ & 0.04 \\
\hline $\mathrm{DM}, \mathrm{n}(\%)$ & $16(29.6 \%)$ & $14(28.6 \%)$ & 0.906 \\
\hline Cardiac disease group, $\mathrm{n}(\%)$ & $31(57.4 \%)$ & $29(59.2 \%)$ & 0.855 \\
\hline Renal disease group, $\mathrm{n}(\%)$ & $15(27.8 \%)$ & $12(24.5 \%)$ & 0.705 \\
\hline Pulmonary disease group, $\mathrm{n}(\%)$ & $17(31.5 \%)$ & $5(10.2 \%)$ & 0.009 \\
\hline $\begin{array}{l}\text { Pleural effusion side, } \mathrm{n}(\%) \\
\mathrm{L} \\
\mathrm{R} \\
\text { Bilateral }\end{array}$ & $\begin{array}{l}20(37.0 \%) \\
32(59.3 \%) \\
2(3.7 \%)\end{array}$ & $\begin{array}{l}12(24.5 \%) \\
31(63.3 \%) \\
6(12.2 \%)\end{array}$ & 0.06 \\
\hline Malignancy detection in pleural fluid, n (\%) & $1(1.9 \%)$ & $4(8.2 \%)$ & 0.189 \\
\hline Duration of drainage, day \pm SD & $8.5 \pm 9.3$ & $9.2 \pm 7.4$ & 0.763 \\
\hline Need for a second surgical procedure at hospitalization, $\mathrm{n}(\%)$ & $19(35.2 \%)$ & $12(24.5 \%)$ & 0.237 \\
\hline Length of hospitalization, day \pm SD & $23.7 \pm 16.8$ & $23.5 \pm 21.2$ & 0.451 \\
\hline
\end{tabular}

L: Left, R: Right, n: Number, SD: Standard deviation, DM: Diabetes mellitus. P values marked with Bold show statistical significance. The p-value written in italics shows that there is a statistically close relationship to significance 
However, in PEs accumulating due to any malignancy, recurrent fluid accumulation in the pleural cavity may be observed after surgical drainage. Pleural drainage in these patients provides short-term symptomatic improvement (14). Therefore, the decision for pleural fluid drainage should be taken with a multidisciplinary approach, and treatment strategies should be determined before and after drainage.

Frequently, patients had drainage using a thin-diameter pleural drainage catheter, but complications developed in one out of every ten patients undergoing drainage. In addition, an additional pleural intervention was required in one of every three patients whose pleural catheter was removed after the drainage was thought to be medically and surgically completed. In the literature, $5 \%-12 \%$ of patients undergoing pleural fluid drainage have been reported to develop complications (14-17). In the current study, postprocedural complications developed in 11 (10.7\%) patients. These results were consistent with the literature.

Therefore, close follow-up of patients undergoing pleural drainage in terms of possible complications (often pneumothorax) is important. In addition, frequent recurrences in patients with a pleural catheter removal due to drainage completion and lung expansion suggest the need for aggressive treatment for the primary condition. It should be kept in mind that pleural fluid accumulates again as the primary disease is not controlled medically.

Table 3. Comparison of mortality and discharged patients

Variables

Age, year \pm SD

Sex, $n(\%)$

Male

Female

Anticoagulant drug use, $\mathrm{n}(\%)$

Number of comorbidities, $n(\%)$

1

2

3 or more

Malignancy presence, $\mathrm{n}(\%)$

DM, n (\%)

Cardiac disease group, $\mathrm{n}(\%)$

Renal disease group, $\mathrm{n}(\%)$

Pulmonary disease group, $\mathrm{n}(\%)$

Pleural effusion side, $\mathrm{n}(\%)$

L

R

Bilateral

\begin{tabular}{lll} 
Discharge $(n=89)$ & Ex $(n=14)$ & $p$ \\
\hline $62.9 \pm 16.5$ & $59.6 \pm 18.4$ & 0.551 \\
\hline $4(53.9 \%)$ & $\begin{array}{l}10(71.4 \%) \\
41(46.1 \%)\end{array}$ & 0.259 \\
\hline $10(11.2 \%)$ & $2(14.3 \%)$ & 0.666 \\
\hline $30(33.7 \%)$ & $3(21.4 \%)$ & \\
$15(16.9 \%)$ & $2(14.3 \%)$ & 0.293 \\
$44(49.4 \%)$ & $9(64.3 \%)$ & \\
\hline $41(46.1 \%)$ & $9(64.3 \%)$ & 0.205 \\
\hline $26(29.2 \%)$ & $4(28.6 \%)$ & 1.000 \\
\hline $51(57.3 \%)$ & $9(64.3 \%)$ & 0.622 \\
\hline $22(24.7 \%)$ & $5(35.7 \%)$ & 0.385 \\
\hline $19(21.3 \%)$ & $3(21.4 \%)$ & 1.000 \\
\hline $30(33.7 \%)$ & $2(14.3 \%)$ & \\
\hline $52(58.4 \%)$ & $11(78.6 \%)$ & 0.263 \\
$7(7.9 \%)$ & $1(7.1 \%)$ & \\
\hline
\end{tabular}

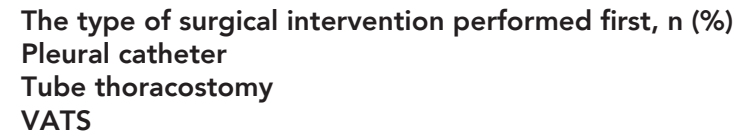

The type of surgical intervention performed first, $n$ (\%)

Pleural catheter

Tube thoracostomy

VATS

\begin{tabular}{|c|c|c|c|}
\hline & & & \\
\hline Surgery-related complication, $\mathrm{n}(\%)$ & $10(11.2 \%)$ & $1(7.1 \%)$ & 1.000 \\
\hline \multicolumn{4}{|l|}{ Type of PE, n (\%) } \\
\hline Transudate & 50 (56.2\%) & $4(28.6 \%)$ & \multirow{2}{*}{0.08} \\
\hline Exudate & $39(43.8 \%)$ & $10(71.4 \%)$ & \\
\hline Malignancy detection in pleural fluid, $\mathrm{n}(\%)$ & $5(5.6 \%)$ & $0(0.0 \%)$ & 1.000 \\
\hline Duration of drainage, day \pm SD & $8.9 \pm 8.8$ & $8.7 \pm 5.5$ & 0.636 \\
\hline Need for a second surgical procedure at hospitalization, $\mathrm{n}(\%)$ & $27(30.3 \%)$ & $4(28.6 \%)$ & 1.000 \\
\hline Length of hospitalization, day \pm SD & $24.8 \pm 19.8$ & $16.2 \pm 8.8$ & 0.160 \\
\hline
\end{tabular}

L: Left, R: Right, n: Number, SD: Standard deviation, VATS: Video-assisted thoracoscopic surgery, The p-value written in italics shows that there is a statistically close relationship to significance 
The number of comorbidities was not found to be significant in terms of the discrepancy between the transudative and exudative fluid, whereas the presence of fluid was observed to differ according to the additional comorbidity. Exudative fluid was frequently observed in patients diagnosed with malignancy, whereas transudative fluid was significantly higher in patients with pulmonary disease. Malignancies are among the most common causes of exudative PE in the studies performed $(11,18)$.

Exudative fluid has been often expected in patients with pulmonary diseases, contrarily, in the current study, transudate fluid was more common in those patients due to the concurrent presence of additional comorbidities, especially cardiac diseases, in those with pulmonary disease.

Considering that the causes of mortality in the United States of America have been examined with age-standardized rates, the mortality rate of patients with pleural fluid has been generally reported as $0.0003 \%$. Data on mortality due to $P E s$ are generally associated with malignant pleural fluids, which is identified with high mortality (19). Studies reported that patients with malignant PE have a high mortality rate. Moreover, mortality was reported in patients with benign etiology, congestive heart failure, and renal failure, which are among the causes of PE. Studies in the literature regarding mortality in non-malignant PEs are limited. In addition, studies reported that bilateral PE is linked with high mortality (19).

In our study, the rate of mortality was not changed by any of the factors. However, a high mortality rate was detected at a level close to statistical significance in patients with both malignancy and exudative fluid, which is also compatible with the literature. In addition, it should not be forgotten that this mortality rate belongs only to hospitalized patients. Thus, results may change during the follow-up examination.

Performing a cytological examination of the pleural fluid in every patient who is hospitalized with PE is still controversial. In the present study, every patient who was found to have malignant pleural fluid on cytological examination had a history of the primary malignancy. No malignancy was detected in the pleural fluid of patients without primary malignancy. Studies in the literature reported that cytological studies were performed in patients who were diagnosed with primary malignancy or who were thought to have malignancy with a high probability. This situation in the current study is compatible with cytological studies in the literature (20). Thus, cytological analysis is thought to be ineffective in patients without a primary malignancy or a pre-diagnosis in this context.
This retrospective study observed a long LOS of patients hospitalized and undergoing pleural drainage due to PE. The average LOS of all patients was 23.6 days. Among these patients, this period was even longer in patients undergoing surgical drainage for the second time, which was 31.7 days on average. Studies evaluating patients who did not undergo pleural drainage reported a shorter LOS. The average LOS was reported to be $4.1 \pm 6.2$ days (21) in a study in which patients who are hospitalized for upper gastrointestinal bleeding were evaluated. Another study examining the community-acquired pneumonia cases detected an average LOS of 11.1 days (22).

\section{Study Limitations}

One of the limitations of our study is its retrospective nature. Other limitations are the number of cases and compromising only drainage applied to patients.

\section{CONCLUSION}

Patients who are hospitalized with PE-caused drainage indicated at least one systemic disease. The most common is cardiac disease. The number of post-drainage complications is moderate; however, major complications are not frequent. Factors affecting the mortality were often due to the primary systemic disease of the patient, whereas the type of PE being exudative may be predictive in terms of mortality. Malignant cells are likely seen in the pleural fluid in the developing PE in patients with malignancy, thus patients without known previous malignancy and those with comorbidities that may cause transudative $P E$, such as heart failure, renal insufficiency, and systemic infections, cytological examination of the pleural fluid may not be requested unless there is strong suspicion. The rate of second pleural surgery is high in PE, thus the LOS of patients is prolonged.

\section{ETHICS}

Ethics Committee Approval: The study was obtained from the Ethics Committee of the University of Health Sciences Turkey, Bakırkoy Dr. Sadi Konuk Training and Research Hospital (protocol number: 2021/96).

Informed Consent: Informed consent for the patient's information was obtained from the patient(s) or a legally authorized representative before hospitalization.

\section{Authorship Contributions}

Surgical and Medical Practices: S.Ö., F.K., N.Ç., Concept: S.Ö., A.K., Design: S.Ö., N.Ç., M.Ö.U., Data Collection or Processing: S.Ö., F.K., N.Ç., Analysis or Interpretation: S.Ö., F.K., N.Ç., M.Ö.U., Literature Search: S.Ö., N.Ç., Writing: S.Ö., F.K., N.Ç., M.Ö.U., A.K. 
Conflict of Interest: No conflict of interest was declared by the authors.

Financial Disclosure: The authors declared that this study received no financial support.

\section{REFERENCES}

1. Kaplan G, Yakut iH, Cinel G. Çocukluk Çağı Plevral Efüzyon Nedenleri, Klinik Bulguları ve Yönetimi; Retrospektif Bir Analiz. Türkiye Çocuk Hast Derg 2021;1:1-5.

2. Çıtak N, Omaygenç DÖ. Plevral Efüzyonda Cerrahi Tedavi Yöntemleri: Tekrarlayan Torasentez, Tüp Torakostomi, Kimyasal Plörodezis, Kalıcı Plevral Kateter, Plevroperitoneal Şant ve Plevrektomi/Dekortikasyon. Güncel Göğüs Hastalıkları Serisi 2015;3:362-79.

3. Metintaş S. Plevral sıvıların epidemiyolojisi. İç: Gözü O, Köktürk O, ed. Plevra hastalıkları. Ankara: Toraks Kitapları-Toraks Derneği Yayınları; 2003:16-23.

4. Hooper C, Lee YG, Maskell N. Erişkinlerdeki tek tarafli plevral efüzyonlarin araştirilmasi: britanya toraks derneği plevral hastaliklar kılavuzu 2010:1-20.

5. Miserocchi G. Physiology and pathophysiology of pleural fluid turnover. Eur Respir J 1997;10:219-25.

6. Light RW. Clinical practice. Pleural effusion. N Engl J Med 2002;346:1971-7.

7. Esendağlı D, Maden E. Sistemik hastalıklarına bağlı plevral efüzyon. Güncel Göğüs Hastalıkları Serisi 2015;3:402-8.

8. Maskell NA, Butland RJ; Pleural Diseases Group, Standards of Care Committee, British Thoracic Society. BTS guidelines for the investigation of a unilateral pleural effusion in adults. Thorax 2003;58:ii8-17.

9. McGrath EE, Anderson PB. Diagnosis of pleural effusion: a systematic approach. Am J Crit Care 2011;20:119-28.

10. Light RW. Diagnostic principles in pleural disease. Eur Respir J 1997; 10:476-81.

11. Marel M. Epidemiology of pleural effusions. Eur Respir Mon 2002;22:146-56.
12. Light RW. Diagnostic approach in a patient with pleural effusion. Eur Respir Mon 2002;22:131-6.

13. Antunes G, Neville E, Duffy J, Ali N; Pleural Diseases Group, Standards of Care Committee, British Thoracic Society. BTS guidelines for the management of malignant pleural effusions. Thorax 2003;58:ii29-38.

14. Koyuncu N. İbrahim A. Pleuracan Drainage due to Pleural Effusion in the Emergency Department Haydarpasa Numune Med J 2019;59:60-3.

15. Kohan JM, Poe RH, Israel RH, Kennedy JD, Benazzi RB, Kallay $M C$, et al. Value of chest ultrasonography versus decubitus roentgenography for thoracentesis. Am Rev Respir Dis 1986;133:1124-6.

16. Collins TR, Sahn SA. Thoracocentesis. Clinical value, complications, technical problems, and patient experience. Chest 1987;91:817-22.

17. Bartter T, Mayo PD, Pratter MR, Santarelli RJ, Leeds WM, Akers SM. Lower risk and higher yield for thoracentesis when performed by experienced operators. Chest 1993;103:1873-6.

18. Maartens G, Bateman ED. Tuberculous pleural effusions: increased culture yield with bedside inoculation of pleural fluid and poor diagnostic value of adenosine deaminase. Thorax 1991;46:96-9.

19. DeBiasi EM, Pisani MA, Murphy TE, Araujo K, Kookoolis A, Argento $A C$, et al. Mortality among patients with pleural effusion undergoing thoracentesis. Eur Respir J 2015;46:495-502.

20. Hsu C. Cytologic detection of malignancy in pleural effusion: a review of 5,255 samples from 3,811 patients. Diagn Cytopathol 1987;3:8-12.

21. Sarı O, Tanoğlu A, İnal V, Türkoğlu Hi, Öztürk B, Sağlam K. GATA Acil Dahiliye Kliniğinde üst gastrointestinal sistem kanaması nedeniyle 1998-2005 yılları arasında takip edilen hastaların sosyodemografik özelliklerinin incelenmesi. Gülhane Tıp Dergisi 2007;49;4:226-31.

22. Pişkin N, Aydemir H, Oztoprak N, Akduman D, Celebi G, Seremet Keskin A. Toplum kökenli pnömoni olgularinda hastanede yatiş süresi ve mortaliteyi etkileyen faktörler [Factors effecting the duration of hospitalization and mortality in patients with community-acquired pneumonia]. Mikrobiyol Bul 2009;43:597-606. 